\title{
The Interaction between the State and Small Business in Russian Regions
}

Bagautdinova N.G.

Panasyuk M.V.

Gafurov I.R.

Shaiheeva D.H.

\author{
Kazan Federal University, Institute of Management, Economics and Finance, Kazan, 420008, Russia
}

Email:mp3719@yandex.ruu

\section{Doi:10.5901/mjss.2014.v5n28p60}

\begin{abstract}
The research is devoted to the issue of the prospects of small and medium-sized businesses influence on economic development of the country. The state support of development of small and medium business in Russia at the Federal and regional levels have been investigated. The analysis of experience in the development of small and medium business in several countries around the world was conducted. According to obtained results key directions of development of small and medium business in the region are revealed, recommendations for local authorities to support small and medium enterprises are given.
\end{abstract}

Keywords: entrepreneurship, small and medium businesses, government support of business

\section{Introduction}

Factor of technological development largely affects the decision making of the line of economic development, its main objectives at this stage. Existing and prospective economic structure determines high priority of new technologies that reduce the importance of the scale of enterprises in many types of economic activity, allowing small and medium-sized enterprises (SMSE) to provide a high level of competitiveness at the national and international markets [7, 10, 11]. In this respect, the importance of the problem of analysis of development prospects of SMSE, their potential contribution to countries economy in the near-term and distant future amid an increasing change in technological fundamentals of the economy is obvious.

In member countries of the Organization for economic cooperation and development (OECD) small and mediumsized enterprises share is more than $95 \%$ of firms, providing $60-70 \%$ of employment and generate a considerable part of new jobs[1].

Small business is concentrated mainly in the sphere of trade and services, as for medium-sized companies - they work in the industries producing product with higher value added - manufacturing, real estate development, agriculture. Moreover, medium-sized business has created from scratch or seriously upgraded such economic activities as a network retail, consumer lending, cellular telephony, private medicine, information technology, poultry, meat processing. This is usually innovative, high-performance company, playing an increasingly important role in economies of developed countries [2, 9]. Recently, franchise has also become a popular growth area for small and medium-sized businesses.

However, in Russian economy small and medium-sized enterprises do not act as a driver of economic development. SMSE share in Russia's GDP is about 20\%. The same one in the UK, Germany, France is in the range of $50-60 \%$, and in Italy is more than $80 \%$. Meanwhile, the state has set impressive targets for 2014-2016. During this period the number of individual entrepreneurs should be increased by 2 million, from small businesses it is expected to create 1.2 million jobs, while in medium-sized companies investment increase by $50 \%$ should take place [2].

Prediction of this increase may be due also to orientation of the government to withdraw a large number of small and medium-sized enterprises from the informal sector. It is necessary to motivate people to officially register their economic activities, because the economy suffer losses in tax collection caused by unresolved status of this problem. 


\section{International Experience of Interaction between Government and SMSEs}

\subsection{The Experience of the Republic of Korea.}

The Korean government relies on the development of innovative small and medium enterprises and investment in research and development. It allocates large amounts of public funds (about 957 million (14.2\% of total investment in research for small and medium-sized business) in 2010) for small and medium-sized enterprises to promote innovative development of SMSEs and SMSE development in regions. Economic growth through innovation in South Korea in the last two decades was mainly due to giant companies (the so-called chaebol such as Samsung, LG, Hyundai and others), but small and medium-sized enterprises played an important role too.

Korean small and medium-sized business operates as one of the strategic foundations of the national economy and makes an important contribution to the economy, ensuring the creation of new jobs, creating leverage, necessary for strong, sustainable and balanced growth in the global economic system. Figure 1 shows some of economic performance of SMSEs in Korea.

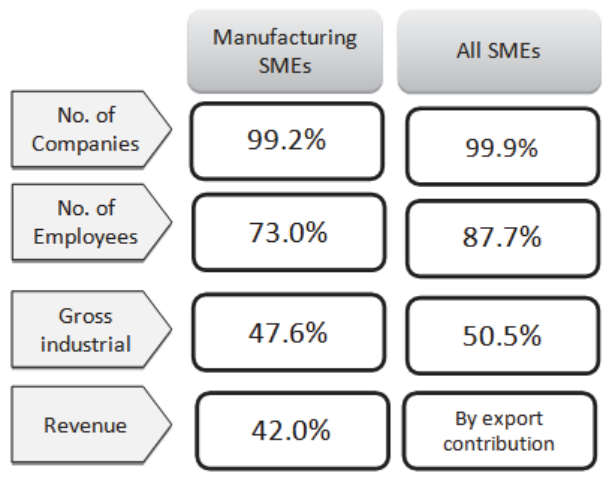

Figure 1. Small and medium-sized enterprises of Republic of Korea [1]

Goals of local industrial policy, including development of supporting technologies are to narrow the gap in region's economy in and to increase GDRP. In addition, the Korean government focused on investments in the expansion of local infrastructure. Since 1999 "Technological support for development and strengthening of industry competitiveness" program at a local level, is conducted using funds provided by the national budget. Local authorities can initiate directions of local industrial policy, which are divided into six parts: technological assistance, support infrastructure, HR, consulting, promotion and development of local business community. According to the Department of knowledge, technological assistance is of $23.3 \%$ of the total investment amongst six parts of the local industrial policy, which amounts about 182 million in 2008 in monetary terms[1, 8].

\subsection{The Experience Of China}

In China, SMSEs made an invaluable contribution to modernization and development of the country. It is now widely recognized that small and medium-sized enterprises play a significant role in the development of many regions, both in China and abroad. During the tenth five-year plan an annual growth of China's economy by $9.5 \%$ on average, and an increase of $28 \%$ for small and medium enterprises were registered. After reforms and open policy in the last two decades, small and medium-sized enterprises have become an important part of the economy of Guangdong province. In 2006, SMSEs in Guangdong province amounted to more than $99 \%$ of enterprises in total, which produce $66 \%$ of the gross industrial output and contribute $70 \%$ in taxes. In addition, they provide more than $80 \%$ of jobs in cities and towns, acting positively in reducing unemployment [5].

\subsection{Small and medium-sized enterprises in Indonesia}

In December 2012, there were 69249 villages, evenly distributed throughout the archipelago in Indonesia. However, their economic situation is not the same. According to the Chairman of the Association of socially vulnerable groups in the district Jayabaya Mulyadi more than 32000 villages in Indonesia found themselves in a category of "left behind". One of 
the ways of growth for municipalities is the promotion of small and medium-sized enterprises. In Indonesia, SMSEs are the backbone of the economy. They accounted for $60 \%$ of GDP and $97 \%$ of the workforce. The development of the SMSEs system will take place through creation of associations, such as cooperatives, business incubators and other forms, which can accelerate the growth of small and medium enterprises, especially in poor villages.

Form of business incubators that can help to use efficiently existing enterprises natural resources, but, however, will not solve the problem of lack of human and financial resources is more flexible in law in Indonesia [6]. If it is necessary for concept of incubator to work successfully, the incubator should be considered as part of the overall strategy of local economic development.

Analyzing the experience of the Republic of Korea it should be noted that it is necessary to give more selfdetermination on the choice of directions of development to local authorities, for development of high-tech industries regular investments in scientific investigations is required, and it is not necessary to create a big-sized research centers, it is enough to stimulate innovative development of SMSEs. However, one should take into account the example of Indonesia, which demonstrate that it is impossible to develop small and medium-sized enterprises, forgetting about the three fundamental factors of production: land, labor and capital.

\section{Problems of Interaction between Government and SMSEs in Russian Regions}

The basic law governing relations between the state and small and medium-sized businesses in Russia is the Federal Law of July 24, 2007 \#209-FZ "On the Development of Small and Medium-sized Entrepreneurship in the Russian Federation"

The law established basic criteria for enterprises and organizations classification to the category of small and medium-sized, principles and objectives of the state policy in this sphere as well as legal regulation. From the point of view of financial regulation, such forms of state support of subjects of small and medium-sized business as financial, property, consulting, information and other are determined. As a matter of practice support is determined by additional regulations.

In 2014 rates of insurance contributions for individual entrepreneurs were reduced and, most importantly, tied to revenue. This initiative, according to preliminary estimates, may return hundreds of thousands of entrepreneurs to the ranks of taxpayers. It is assumed that it will alleviate the financial burden for $20 \%$ of registered individual entrepreneurs in the sphere of small and medium-sized businesses.

The tax code provides several special tax regimes. The State Duma is currently considering the bill according to in 2014 it is proposed to increase maximum amount of income for transition to simplified taxation system (STS) up to 150 million rubles. This measure will allow more small and medium-sized enterprises to pay taxes under the simplified system. The steps that have been done already led to positive dynamics: recent statistics indicate an increase in the number of entrepreneurs and enterprises.

It is worth mentioning other measures of state support. SMSEs have an access to public procurement: public and municipal customers are required to place at least 15\% of orders from small businesses. By 2015 it is planned to increase this figure up to $18 \%$, and in 2018 - up to $25 \%$. Restrictions on the list of purchased goods, works and services are removed, and initial contract price is increased to 20 million [2]. One must also highlight a group of measures to support lending to small and medium-sized businesses on preferential terms.

Specificity of the Russian Federal state, complexity of territorial organization of economy has led to increased differentiation of national economic spaces and regional imbalances. The abandonment of the concept of leveling economic and social development of Russian Federation entities, recognition of benefits of polarized regions has necessitated recognition of the differences in forms of implementation of entrepreneurial activity within the individual regional entities that required development adapted to the peculiarities of state regulation of entrepreneurial activity [3].

This leads to the fact that development of specific measures to stimulate development of small and medium business in Russia are mainly elaborated by regional and municipal authorities. They provide most of assistance to small and medium-sized enterprises, having complete information about situation in a region.

Among the main problems of SMSEs development at regional and municipal levels we should note the fact that a budget of municipality depends on regional and Federal budget subsidies by about two thirds, respectively, they struggle for the increase of this part more than for the development of entrepreneurship. Therefore, our country needs a system of incentives to municipalities for development of small and medium-sized businesses. In this regard, the decision of the Ministry of economic development to increase the responsibility of local authorities for development of small and medium business in the region and the provision of subsidies depending on the results of the work in this direction seems to be rather promising. 
An acute problem, reducing motivation of local municipalities in the development of small and medium business, is the large number of formal work (according to the interviewed decision makers, up to $70 \%$ of the time), this work requires special skills and staff increasing that is in conflict with the principle of budgetary savings, laid down in the Federal law on local self-government [4].

In the light of the foregoing, analysis of development programs of small and medium-sized enterprises in the municipal units of the Republic of Tatarstan was conducted. Basing on the analysis the following weaknesses in the interaction between businesses and local municipalities were revealed:

- A large share of the municipal units of the Republic of Tatarstan has a municipal program for development of small and medium-sized businesses, or a special section in socio-economic development programs of a region on business activity. However, there is no transparency in the rationale for any given planned programs of activities. Reports on the progress of programs and achievement of indicators are extremely rare;

- Public activities of business associations are not developed, there is no information about meetings of such communities, a business community has a weak effect on the local municipalities;

- There are very little training activities;

- In reports of municipalities authorities and on the website of the Federal service of state statistics of Tatarstan there are no detailed data on the development of small and medium enterprises in selected locations, making it difficult to track a real picture of development of small and medium-sized business in the Republic.

\section{Conclusions}

Considering factors of sustainable development of regional economy, it is important to note a role of small and mediumsized business.

On the basis of conducted analysis a number of recommendations for cooperation of small and medium-sized businesses and regional government and local self-government are elaborated:

- Programs of development of small and medium-sized entrepreneurship should be developed locally, at the level of municipality, taking into account economic and geographical position of a region, resource base, sectorial focus of territory economy, demographic indicators. Special attention should be paid to analysis and regulation of business climate. It is necessary to conduct antitrust policy and anti-corruption programs.

- Program for development of small and medium-sized business should have a detailed study, a reasoned justification for decision-making. Text of the program of development of small and medium-sized enterprises of municipality should be available to all residents of a region, as it is not only a plan, but also a motivating factor for local entrepreneurs.

- It is important to promote and enhance business community and to re-establish dialogue with local authorities. This can be significant in high-quality development programs for small and medium-sized enterprises.

- It is possible to build an effective economy with a high share of small and medium-sized enterprises only under condition of well-coordinated work of representatives of authorities, business and society (consumers, local residents).

\section{References}

Soogwan, Doh, Byungkyu Kim (2014) Government Support for SME innovations in the regional industries: The case of government financial support program in South Korea, Research Policy, 43, 1557-1569

Trends and prospects of development of small and medium business in Russia. [Electronic resource] Media project of the Great Epoch 2014. See http://www.epochtimes.ru/universitet-sinergiya-tendentsii-i-perspektivy-razvitiya-malogo-i-srednego-biznesa-v-rossii98915842/ (date of access 14.11.14)

Talev M. C. (2013) Development of involuntary and voluntary entrepreneurship in conjunction with the peculiarities of the territorial organization of economy. Thesis, FGBOU VPO "Mari state University, Yoshkar-Ola, 2013, p.4.

Scale A. C. (2009) Small town: a SWOT analysis of the problem field, Journal of Regional Studies, 9-18.

Qian, Qinglan, Chen, Yinbiao (2011) SME, Technological Innovation and Regional Environment: The Case of Guangdong, China, Procedia - Earth and Planetary Science, 2, 327-333

Zoel Hutabarat, Marcelino Pandin (2014) Absorptive Capacity of Business Incubator for SME"s Rural Community Located in Indonesia's Village, Procedia - Social and Behavioral Sciences, 115, 373-377

Gorondutse, A.H., Hilman, H. (2014) Effect of business social responsibility (BSR) on performance of SMEs: Data screening and preliminary analysis, Asian Social Science, 10 (8), 103-115.

Suh, Y., Kim, M.-S. (2014) Internationally leading SMEs vs. internationalized SMEs: Evidence of success factors from South Korea, 
International Business Review, 23 (1), pp. 115-129.

McAdam, R., Reid, R., Shevlin, M. (2014) Determinants for innovation implementation at SME and inter SME levels within peripheral regions, International Journal of Entrepreneurial Behaviour and Research, 20 (1), 66-90.

Tan, C.S.L., Smyrnios, K.X., Xiong, L. (2014) What drives learning orientation in fast growth SMEs? International Journal of Entrepreneurial Behaviour and Research, 20 (4), 324-350.

Foreman-Peck, J. (2013) Effectiveness and efficiency of SME innovation policy, Small Business Economics, 41 (1), 55-70.

Egorov, E.,Razumovskaya, E.,Tarhanov, I., Kucevol, N.,Calikova, V. Methodological bases of system of social service of the population. Middle East Journal of Scientific Research vol. 18 (1), pp. 9-12.

Razumovskaya, E.M. , Kutsevol, N., Popov, M., Mishakin, T., Leto, L., Tsalikova, V. The effectiveness of management practice in the market of socially important services. Asian Social Science, Volume 10, 28 September 2014, Pages 118-122.

Razumovskaya, E.M.,Lapidus, L.V., Mishakin, T.S., Popov, M.L. Features and peculiarities of the Russian passenger rail market development. Mediterranean Journal of Social Sciences vol. 5 (18 SPEC. ISSUE), pp. 165-170.

Palei Tatyana, Salakhatdinova Leisian. The study of the phenomenon of creativity in education. Procedia - Social and Behavioral Sciences Vol. 131, pp. 90-96// 3rd World conference on educational technology researches. Turkey 07-09.11.2013. 